\title{
Expeditions
}

\section{Water Scarcity in Brazil: A Case Study \\ A Case Study}

Denise Slater

https://doi.org/10.36304/ExpwMCUP.2019.02

Abstract: Between 2012 and 2015, Brazil experienced one of the worst droughts in its history. A combination of natural and human-made causes-including climate change, environmental degradation, poor urban planning, a lack of maintenance of existing infrastructure, corruption, and the mismanagement of water resources-contributed to a growing water crisis. This article will focus on the effects of both the drought and the subsequent water crisis on the vast metropolitan area of the city of São Paulo, illustrating how both natural and human factors combined to create a crisis in Brazil's largest city.

Keywords: Brazil, Amazon Rainforest, water crisis, water scarcity, drought, corruption, pollution, deforestation, climate change, environmental law, politics, Latin America

Denise Slater is a Latin America subject matter expert, a researcher, and an analyst who possesses 14 years of experience developing projects for the U.S. Department of Defense. She is currently employed by Corps Solutions as the principal Latin American analyst for the Regional Culture and Language Familiarization Program at Marine Corps University in Quantico, Virginia. Her research on Latin America includes geopolitics, regional security, military culture, corruption and governance, military institutions, and environmental issues. Born and raised in Brazil, Slater received her undergraduate degree in international relations from the University of Brasília and her master's degree in international studies from Old Dominion University in Norfolk, Virginia. 
Water scarcity affects many regions of the world, and it is a growing problem, primarily due to population growth and intense conflict in historically waterstressed regions. Water scarcity is typically associated with arid parts of the world, such as the Middle East and North Africa. In recent years, however, freshwater supply shortages are also occurring in unexpected parts of the world and countries known for their water resources, including Brazil. Someone familiar with South America would not be surprised to read about the dry Sertão (roughly translated as backcountry or bush) in northeast Brazil, but a lack of water in south or southeast Brazil is unexpected. This article will explain how regional climate change, human-made environmental changes, corruption, and general infrastructure mismanagement combined to create a water supply problem where none should exist-or, at least, not as severely as the one described below. The complex interaction of these discrete variables helps explain how this water supply crisis went undetected for so long and may serve as a warning to other growing urban areas that are also currently beginning to experience similar shortages.

While natural factors contribute to water shortages, human factors are significant to the Brazilian case, where widespread corruption and graft have hindered infrastructure projects and propelled the water supply crisis to unprecedented levels. Corruption in the wake of large infrastructure projects in the developing world is not exclusive to Brazil. Such predictability is due to many issues, including a lack of transparency, weak institutions, and low accountability. The results of corrupt practices are financial loss, environmental damage, and continued risk to human health and lives. In Brazil, corruption continues to be the main internal factor causing the country's water crisis. For example, when Brazil was in the spotlight during the 2016 Olympic Games, which took place in 
Rio de Janeiro, Brazilian officials could not explain how the Guanabara Bay remained grossly polluted despite hefty loans directed to that project from the Inter-American Development Bank (IDB) and other donors for more than 30 years. 1 If Brazilian authorities allowed for such a fiasco while the entire world was paying attention, one can only imagine what could become of lesser-known infrastructure projects when no one is watching.

From 2012 to 2015, Brazil experienced one of the worst droughts in its history. A similar severe drought affected much of the Western Hemisphereincluding the United States, Mexico, and Central America-during that same period. Several other interrelated external and internal factors also contributed to an unforeseen water crisis in Brazil. Climate change, environmental degradation, poor urban planning, a lack of maintenance of existing infrastructure, corruption, and the chronic mismanagement of water resources all worked together to create a cycle of pollution and waste. 2

The following study will focus on the 2012-15 drought in the large metropolitan area of the city of São Paulo, located in the southeastern state of São Paulo. The objective of this article is to explore the relationship between the natural and human factors contributing to the water supply crisis in São Paulo. Though the city has good water management laws on the books, it is clear that Brazilian officials have played a significant role in exacerbating the water crisis by ignoring many of these laws and allowing for the poor planning, neglect, and mismanagement of one the nation's most essential resources.

\section{Geographic Synopsis}

Brazil is the largest country in South America and roughly the same size as the continental United States. It is home to the Amazon River, the world's secondlongest river and largest in terms of water volume. Sixty-three percent of the 
Amazon Basin, the largest drainage basin in the world, is located in Brazil, where it occupies 40 percent of the national territory. Within Brazil, there are 12 large hydrographic basins and 83 sub-basins with waters that cross over international borders, 54 of which are in the Amazon Basin to the north and 29 of which are in the Prata Basin to the south.3

These basins surround large rivers, including the lengthy São Francisco River in northeast Brazil and the Paraná, Paraguay, and Uruguay Rivers in the south. In the Amazon Basin, the Tocantins River, a major tributary of the Amazon River, empties in the state of Pará, while the Xingu River flows from the state of Mato Grosso to the Amazon.4 The Tapajós River flows through northeast Brazil, crosses Pará, and ends at the Amazon, as well. Most estimates indicate that 1216 percent of the world's fresh water is located in Brazil.5 With such an abundance of water, why does it suffer from water scarcity?

The apparent water wealth of Brazil masks underlying problems. While water is most plentiful in the low-populated Amazon Basin area, most of the Brazilian population is located in the southeast and northeast regions of the country, almost 2,000 miles away. Even though the Amazon Basin contains the bulk of the country's water, it is home to only 5.1 percent of Brazil's population. Water supply and population distribution do not match up because most people live in metropolitan areas located along the Atlantic coast, especially in megacities such as Rio de Janeiro and São Paulo.6 Because these large urban centers grew exponentially during the twentieth century but were frequently without adequate infrastructure planning, they suffer from a deficient water supply. Severe droughts in recent years have exponentially aggravated the situation.7

What is different about this recent drought is how it affected a region that is more prone to flooding than drought. While northeast Brazil 
encompasses a large semiarid area known as the Sertão and has endured regular cycles of severe drought, famine, and tragedy since the earliest times in recorded history, the southeast region has not. The 2012-15 drought, however, equally affected southeast Brazil, the most populous region in the country. Water scarcity combined with population increase is a crucial concern worldwide. In 2016, the United Nations Educational, Scientific, and Cultural Organization (UNESCO) released a report stating that although "there is enough freshwater on the planet for the world population of about seven billion people, its distribution is uneven in both time and space, and a lot of it is wasted, polluted and managed in an unsustainable manner."8 
Figure 1. NASA Map of Brazil

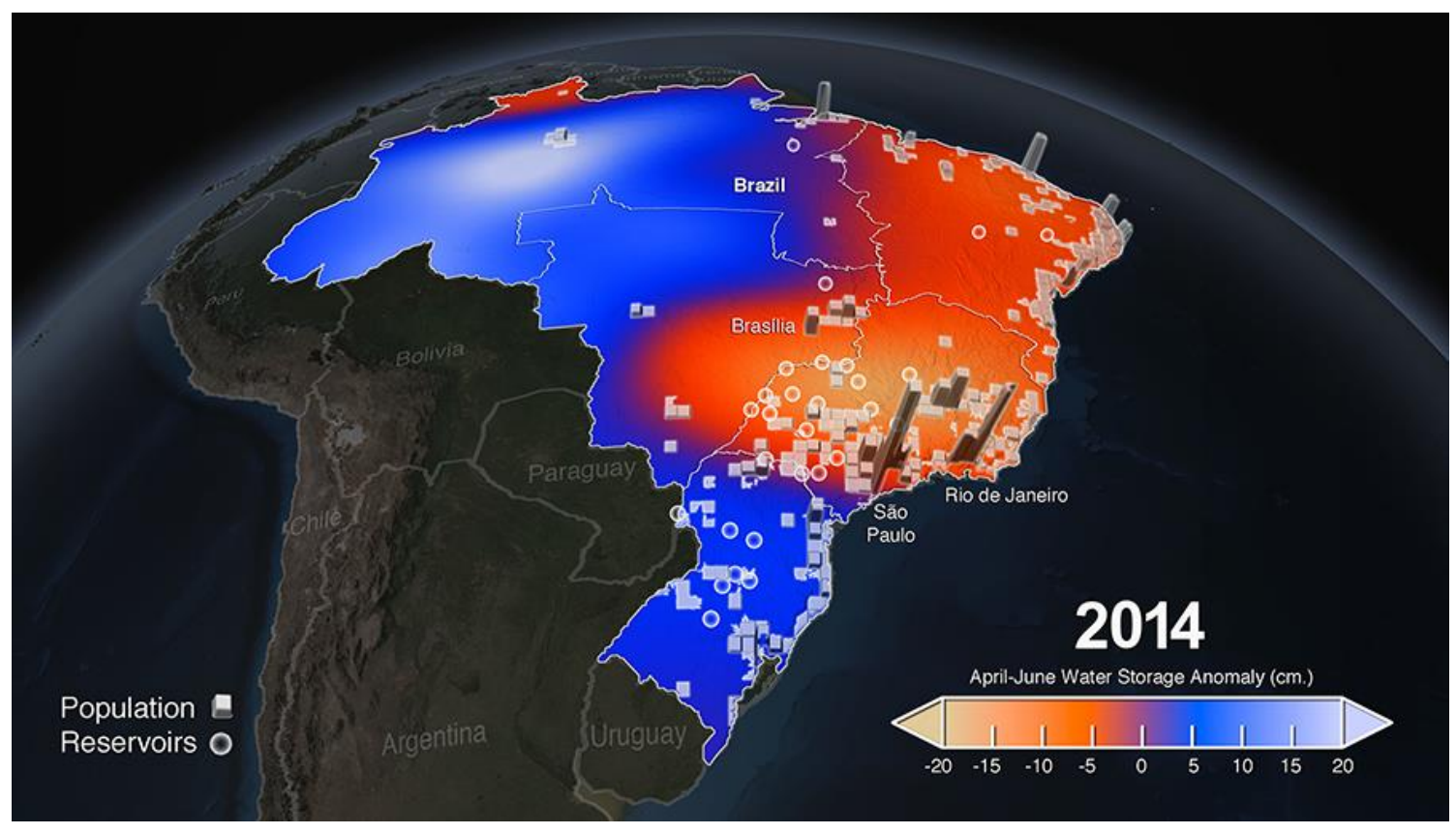

A map displaying Brazil's water storage anomaly, April-June 2014.

Source: NASA Scientific Visualization Studio.

\section{Unique Aspects of Regional Climate Change}

The next step to understanding Brazil's water crisis is to examine the interaction between geography and politics and the impact of climate change. The significant geographic differences between Brazil's regions and demographic pressures account for only part of a complex scenario. Climate also plays a significant role in affecting water resources in these regions, impacting them with cyclical periods of precipitation and drought and other unpredicted climate-related events.9 Climate change studies by various scientific organizations and universities continue to assess possible consequences and risks in Brazil. The Brazilian Agricultural Research Corporation (Embrapa) and the Applied Meteorological and Climatic Centre of Investigation for Agriculture predict a $1^{\circ} \mathrm{C}$ temperature increase by 2020. In this scenario, Brazil's coffee 
production could shrink by as much as 24 percent; soybean production, 14 percent; rice production, 4 percent; and corn production, 2 percent. 10

Alongside global climate change, other climatic factors also affect environmental change in Brazil. The Southern Hemisphere has a different seasonal pattern than the Northern Hemisphere, which has marked seasons. As in most of South America, Brazil's seasons include a rainy period, which typically lasts from October to March, and a dry period, which usually occurs from April to September. However, these two seasons have been subject to increasingly adverse weather patterns known as El Niño and La Niña.

The El Niño and La Niña weather patterns are contrasting periods of the El Niño-Southern Oscillation cycle that are caused by variations in ocean current patterns in the eastern part of the Equatorial Pacific region. During periods that range from 7 to 11 years, warmer currents from the equatorial waters replace the colder Humboldt Currents off the coast of Peru. El Niño brings warmer temperatures and more rainfall than usual in certain areas, while La Niña is responsible for lower temperatures and drier conditions, lasting 9-12 months.11 During El Niño periods, there is excessive rainfall, especially in southeastern South America, which causes severe flooding in the region.12

Rio de Janeiro and São Paulo, the largest cities in South America, are both located in southeast Brazil. Between 2012 and 2015, a particularly severe El Niño aggravated the drought in the historically dry northeast region, but there was no excess of precipitation in the southeast. The rainy season in those years had less rainfall than was expected during the summer months, especially during an El Niño period. There was a simultaneous occurrence of other rare climatic events, including a reduced number of occurrences of the South Atlantic Convergence Zone (SACZ), the most critical mechanism that produces rain in southeast Brazil in the summer, and the strength of South American low-level jet winds.13 Those 
combining events created a water supply crisis in Brazil that was considerably worse than in previous years.

El Niño brings periods of hot spells to the interior of Brazil, causing elevated temperatures in the southern parts of the country and affecting many large cities in the summer. El Niño also aggravates drought conditions in the northeast region, reducing by up to 50 percent its already low rainfall levels and further straining water supplies, hydroelectricity, power plants, and cocoa and coffee production.14 In addition to the severity of disruptions caused by El Niño and La Niña, historical evidence shows that both are also occurring more frequently. While previous studies registered the phenomena happening approximately every 20 years, El Niño occurrences are expected to double in this century, with extreme weather-related events eventually taking place once every decade.15

Climatologists from Brazil's National Institute for Space Research (INPE) have concluded that a chain of combined climatic mechanisms explains the causes of the 2012-15 drought.16 One of their models tracked the drought's initiating factor to anomalous rains in the tropical north of Australia, which set off a sequence of processes that connected with the tropical southeast region of Brazil.17 While their studies did not indicate that the drought was the result of an increase of greenhouse gases in the atmosphere that contributes to global warming, they were able to conclude that the factors most likely responsible to contributing to the water supply crisis in São Paulo were population increase and higher water consumption.18 São Paulo experienced rapid urbanization during the past century, but inadequate infrastructure planning resulted in a deficient water supply. The combination of rare climate events exponentially accelerated and highlighted the effects of that lack of planning, resulting in a critical situation. 


\section{Effects of the Drought in São Paulo}

Brazil relies heavily on hydroelectric power plants as its primary energy source and therefore is particularly vulnerable to droughts. The 2012-15 drought caused electricity to falter in major Brazilian cities. These blackouts—or apagões, as the population commonly refers to them-were caused by depleted water reservoirs, which hindered the capacity of hydroelectric power plants to generate electricity across the country.19 The effects of the drought were particularly pervasive in two regions located thousands of miles apart from each other: the historically drought-prone northeast and the southeast, especially in the city of São Paulo.

There are 645 municipalities in the state of São Paulo, all of which spread across two large hydrographic basins, the Paraná and Atlantic Southeast Basins. More than half of those municipalities rely exclusively on underground water, while 29 percent use surface water and 20 percent use mixed systems.20 The city of São Paulo's water system is managed by Companhia de Saneamento Basico do Estado de São Paulo (SABESP), a mixed capital sanitation company that provides water and sewage service for 364 of the state's municipalities.21

When the drought dried up the city's reservoirs, SABESP officials urged São Paulo residents to limit their water use, since the people held the misguided belief that their city's water supply was unlimited. Indeed, until 2014, the average São Paulo resident used about 200 liters of water per day, considerably more than the average 150 liters used daily in Europe; however, a year of shortages forced the city to reduce its water usage by one-quarter. By January 2015 , one of the city's main water reservoirs, the Cantareira system, was functioning at only 5.4 percent of its capacity.22 The water reserves dropped to a worrisome "dead level," which required a pump to propel the water up so it could reach the pipes 
that lead to the distribution system.23 In early 2015, during the acute water shortage, São Paulo's residents faced a variety of water-related problems. There were dry taps, blackouts, delays on subway trains, and inconsistencies in electricity delivery. The internet faltered for entire days, inconveniencing the population and causing massive financial harm to industries and businesses.

The shortage of water and electricity had a strong negative social impact, affecting the daily routine of millions of people. As the water crisis spread, the frustrated population carried out street demonstrations, demanding immediate government actions to mitigate the crisis. SABESP officials responded to criticism toward their lack of success in mitigating the crisis by claiming they had to deal with "a dual surge of extreme weather and rising demands for a growing and increasingly wealthy population." 24 They tried to skirt the blame by pointing to factors that were out of their control rather than any possible lack of planning for extreme weather events or mismanagement of the water infrastructure on their part.

\section{Brazilian Water Management Laws and Governance}

The previous sections note that the 2012-15 water crisis in São Paulo was the result of population increase and higher water consumption, a conclusion that SABESP officials endorsed. However, a closer look at water legislation in Brazil brings further clarity to the issue, as it provides details of matters of governance that affected the crisis. Climate patterns and the growth of urban populations undoubtedly aggravate Brazilian water problems, but city, state, and national officials often do not enforce the water laws that could help ameliorate some of those issues. The Brazilian Water Code, concerning water resources management, existed since 1934, but it did not provide a model of decentralized and participatory management of water and was mostly ineffective in preventing 
water stress, conflict over water use, and pollution.25 As a result, following heavy criticism and lengthy debates in the 1980s and 1990s, the National Congress of Brazil passed Law \#9433 (a.k.a. The Water Law) in January 1997, aiming to improve the 1934 law.26 On 17 July 2000, Law \#9984 established the National Water Agency (ANA), responsible for implementing the National Water Resources Management System (SINGREH), as determined by the country's 1988 federal constitution.27

The contradictions seen between the intent of Brazil's water laws and their implementation have not gone unnoticed by international bodies watching the developing world. In order to promote positive actions regarding global water management, the United Nations General Assembly declared in 2010 that access to clean water and sanitation is a human right.28 According to the United Nations Educational, Scientific, and Cultural Organization's World Water Assessment Programme (UNESCO WWAP), every country needs to have set in place laws and policies governing the management of water resources. The WWAP also found that "even if all the necessary policies and laws are in place, [the] development of water resources will not take place without adequate funding of infrastructure and the institutional and human capacity of the sector." 29

Though Brazil has laws in place to implement good governance of its water supply and agencies to implement new rules and regulations, problems nevertheless persist. The reality is that what is recorded on paper does not necessarily translate into action. In Brazil, funding infrastructure projects remains a constant challenge, and the actions required to manage and execute the laws are faulty, prone to delays and corruption, or subject to bad choices that favor short-term political gains. 30 
Even with the help of outside organizations, Brazil has a history of conducting large projects in the category of water and sanitation that accomplish very little of their original goals. For instance, in the 1990s, the IDB and other organizations financed part of the cleanup of Rio de Janeiro's polluted Guanabara Bay, which totaled $\$ 800$ million but achieved little. In 2011, the IDB financed a similar cleanup project for the same polluted bay in advance of the 2016 Olympic Games.31 Since its first loans in the 1990s had resulted in a minimal measurable outcome, the IDB required that Rio de Janeiro's State Secretariat of the Environment (SEA), via the Sanitation Program for Municipalities Surrounding the Guanabara Bay (PSAM), serve as the consulting agency responsible for overseeing the 2011 contract.32 Those provisions intended that the former executing agency, Rio de Janeiro's State Company for Water and Sewage (CEDAE), be "kept at arm's length on management and financial decisions." 33

By 2016, accusations of corruption and even murder had plagued the project. Priscilla Pereira, one of PSAM's executives in charge of accounting for the distribution of IDB funds to contractors, was murdered. While her death remains unsolved, foul play is suspected.34 Somehow, a longtime CEDAE executive managed to assume control of PSAM, and CEDAE began proposing projects that would dump more raw sewage in the ocean with the use of money previously allocated to clean up the bay for the Olympics. Consequently, Olympics water sports games took place in the heavily polluted Guanabara Bay.

Such problems related to water and sanitation infrastructure projects exist in many countries in the developing world. Corruption and a lack of accountability and transparency are not problems found in Brazil alone. Most development banks and institutions, such as the World Bank and the IDB, have published extensive studies on the matter and established safety guidelines and 
provisions in loans to mitigate or counter schemes of corruption and graft. 35 Again, WWAP provides valuable insights into this phenomenon: "Legitimate, transparent and participatory processes can effectively mobilize input for designing and implementing water resources policy and create a strong deterrent to corruption." Corruption "remains a poorly addressed governance issue in the water domain. It can lead to uncontrolled pollution of water sources, overpumping and depletion of groundwater, lack of planning, degradation of ecosystems, weakened flood protection, urban expansion leading to heightened water tensions, and other harmful effects." 36 Unfortunately, as the United Nations has found, the fact that Brazil is not unique in its problems with corruption does not make those problems any less thorny to address.

There are plenty of examples of ineffective governance in water resources in Brazil. According to a study entitled The Water Crisis and Its Consequences, published by the Brazilian Federal Senate in 2015, one particularly costly and harmful case occurred because the federal government sent the wrong message to the population. The government-subsidized electricity cut costs while misleading the population into consuming more water-generated electricity when a drought was looming. At the end of 2012, as the 2014 reelection bid for Brazilian President Dilma Rousseff neared, the government issued a populist measure known as Comissão Mista da Medida Provisória Número 579 de 2012 (Temporary Measure No. 579) that would reduce electricity tariffs by 20 percent-a classically populist and politically driven type of policy. Rousseff announced the law with fanfare on 7 September 2012, Brazil's Independence Day, on national radio and television. She boasted, "Brazil is the only country in the world which simultaneously lowered the tariffs and increased electricity production, and there will be no shortage of electricity in Brazil at any given 
time." In her final remarks, she emphasized that "the population can consume all the electricity it wants because it is cheap and abundant." 37

On 18 October 2012, just a few weeks following that announcement, the Brazilian government backtracked after political leaders realized that advertising for cheaper and abundant electricity increased water consumption at the same time that the country's water reservoirs were running low. To remedy that selfinflicted damage, the government issued another directive that proved to be as harmful as the first, ordering "all thermal plants available" that produced energy at prices at least twice as high as hydroelectric plants to "begin operating in a water-saving mode to save water in the reservoirs of the hydroelectric plants." 38 That contradictory message indicated the government's awareness of a looming water shortage and concern with an insufficient amount of electricity while, at the same time, authorizing the higher costs of the production of that service. The negative consequences of those actions affected the entire population.

The above example illustrates how Brazilian politicians have used water resources as if they were unlimited, undermining long-term planning and public safety in favor of immediate political gain using infrastructure and public utilities. By instructing thermal plants to produce electricity as efficiently as possible, it is clear that federal officials knew there was a possibility of a water shortage in 2012. In this particular case, the correct measure would have been for the government to do precisely the opposite by raising the electricity tariff, a much less attractive decision for a populist politician seeking reelection. A higher tariff would have been consistent with the cost of the production and minimized the lack of balance between resources and demand. It is important to note that 2012 was the year the historic drought began in Brazil. That single governmental action accelerated the emptying of the reservoirs in São Paulo, which, when 
coupled with the emerging drought, set the stage for the worst metropolitan water shortage in the history of the country.

\section{Poor Planning and Mismanagement}

In general, long-term planning and funding for large infrastructure projects in Brazil have had mixed results. In the metropolitan area of São Paulo, successive governments have often reacted to water crises and electricity shortages rather than pragmatically carrying out planning and preventive actions. When planning occurs, it is frequently cursory or takes several years to move from the drawing board to implementation, which results in costs that are several times what was projected and takes several years to be completed, if ever.

The Brazilian federal government has charged one agency to monitor urban planning: the Ministry of Cities, created in 2003. That agency, however, failed to provide the timely urban planning needed in the nation and, by January 2019, had been merged with another agency into the Ministry of Regional Development.39 One of the main reasons for its failure is that most politicians in public offices are not able to inaugurate public works projects that take longterm planning during their assigned terms. Projects requiring short-term planning and having a short turnaround period have the immediate advantage of securing votes, primarily if they refer to public works. Since winning elections is their ultimate goal, many of São Paulo's politicians have put off addressing infrastructure matters for more than two decades. The 2012-15 water crisis revealed poor planning, mismanagement, and lack of maintenance of the city's existing infrastructure. The pervasive effects of the drought would have been much less severe had city officials managed and planned responsibly during previous decades. If they had implemented the necessary policies, carried out 
adequate maintenance, implemented infrastructure projects, and conducted urban planning, the recent water supply crisis would not have been so severe.

Poor planning examples are abundant in Brazil's water policies. For instance, SABESP historically favored water expansion investments instead of a balanced approach to the expansion and maintenance of the current grid. There was no maintenance or modernization of the system, which partly contributed to the water crisis. The pipes in the water grid have not been repaired or replaced in several years, and they have high leakage rates ranging from 40 to 45 percent. According to SABESP, 17 percent of the grid is more than 40 years old, and 34 percent is between 30 and 40 years old.40 Any long-term preventive actions for water management must include reducing leaks in the infrastructure.

The massive volume of water wasted each year in São Paulo, and in the Brazilian water system as a whole, is a consequence of years of infrastructure neglect and mismanagement. An independent report entitled Water Losses: Challenges in the Progress of Basic Services and Water Scarcity, produced by GO Associates, provides revealing statistics using official 2013 data from the Brazilian Ministry of Cities. The report sheds light on the heavy losses of water that the faulty Brazilian water infrastructure suffers each year. The authors found that "the volume of total non-billable water in the country equals 6.5 times the capacity of the Cantareira System in São Paulo-the equivalent of 7,154 Olympic-size pools a day or ... the entire production of the city of São Paulo in 5 years." 41

Furthermore, the total amount of water wasted annually throughout the country is approximately 39 percent of all investments in water management and infrastructure combined. The report reveals that regional levels of waste vary widely. The north leads Brazil's regions in water loss at a rate of 60.59 percent. The highest rates of waste per state were 76.54 percent in Amapá and 72.62 
percent in Amazonas, both in the northeast region. The south had the lowest average rate of loss, at about 36 percent, and in São Paulo, the financial loss was below the country's average of 32 percent. 42

Another example of mismanagement was SABESP's handling of water volume management at the Cantareira Reservoir. In this case, the ANA and São Paulo state's Department of Water and Electric Power (DAEE) prescribed that SABESP's operators were allowed a limited amount of water from the reservoir during the drought. Those limits, however, were ignored, which pushed the Cantareira System to the point of almost total collapse. The lack of planning contributed to the reservoir remaining below its operational capacity for most of 2016, even though the drought was over.43 These examples demonstrate that the Brazilian government allocates insufficient efforts toward planning for proper water management for daily water needs, leaving them in a reactionary stance during periods of crisis.

\section{Government Interventions to Counter the Drought}

In place of proper planning and infrastructure maintenance, São Paulo's state government responded to the water crisis with a wide array of solutions and large projects, some of which were more relevant and effective than others. The general public, civil society, nongovernmental organizations, and the media criticized the efficacy, timing, and relevance of those various projects and initiatives for either taking too long to generate relief or for being too risky. In 2014, the government began providing financial incentives to encourage more efficient water use to counter the effects of the looming water shortage. SABESP created a bonus program to reward those that saved water, which caused water usage to decline by 17 percent.44 At the same time, the government also established water rationing, a very contentious political issue that leaders said 
they would not do before the 2014 elections.45 The city's water administration also attempted some risky solutions to minimize water loss through the severely leaky grid, such as lowering the water pressure in the system, which was implemented in several neighborhoods and dried up taps for 7-18 hours in a given day.

The problem with the rationing approach that SABESP effected at the end of 2014 and in 2015 was that lowering the pressure in the water grid increased the risk of contamination.46 SABESP officials also removed entire neighborhoods from the primary water supply system-the Cantareira Reservoir. In the end, SABESP's actions were insufficient to counter the daily water deficits. Water availability fell sharply-water supply dropped by 74 percent in 2014-and measures taken to deal with the shortage were insufficient to maintain the water supply reserves at a safe minimum. 47

The government's actions and solutions to the crisis were both expensive and ill-timed. Its main proposals involved beginning big construction projects, building new reservoirs, and importing water from other states, none of which helped during the first two years of the shortage. For example, a project to connect two water supply systems - the Rio Grande and the Alto Tietê-was essential but poorly timed. The work included the installation of four pumps with the capacity to push water up to 80 meters $(\mathrm{m})$ over hills and through 11 kilometers $(\mathrm{km})$ of pipes between one system and the other. The connection currently pumps water from the Billings Dam, which was at a stable 85.6 percent level in mid-2015, to the Taiaçupeba Dam, which integrates the Alto Tietê systems. The massive project increased water levels by 26 percent and now supplies water to 1.2 million people in Brazil. The connection rescued the Alto Tietê and Cantareira Systems, which were still in a critical situation when the 
project ended on 30 September 2015. At that time, the Cantareira Reservoir had been operating at just 16.2 percent of its capacity.

Other long-term interventions that are still in the works include building a 13-km connection that will bring water from the Paraíba do Sul River Basin in the southeastern state of Rio de Janeiro to the Cantareira System. The project began in February 2016 but was not completed until 2018 due to a lack of environmental permits and other problems.48 The second part of that project includes building a reverse connection from the Cantareira to the Paraíba do Sul River Basin, but there is no estimate for if or when that will be completed. The project generated significant conflict between the three states-São Paulo, Rio de Janeiro, and Minas Gerais-that share the basin and were suffering the effects of the drought and faltering water supply. The legal battle that ensued ended up in the Brazilian Supreme Court, which ultimately approved the project in 2014.49 However, a study done by the World Resources Institute concluded that these new infrastructures contribute little to solving the water security challenges in the region: "Built infrastructure addresses only some of São Paulo's challenges with water insecurity. And new water infrastructure will be just as susceptible to sediment pollution as existing infrastructure." 50

According to São Paulo's city administration, it is vital to integrate the area's seven water supply systems: the Guarapiranga, Cantareira, Alto Tietê, Rio Grande, Rio Claro, Alto, and Baixo Cotia. Then-governor of São Paulo state Geraldo Alckmin explained his strategy of attempting to integrate the river basins by pointing out that "when it rains, it rains too much ... when it is dry, it is too dry ... and sometimes both happen simultaneously. The only way is to integrate the basins to guarantee supply." He further observed, "Some systems are well-supplied with water. Guarapiranga is at 76 percent, Billings is even fuller; it is an uneven system in which one is lower than the other. This new integration 
of the basins will bring safety." 51 Even though the integrated system allows for better distribution among its reservoirs and is safer, the work ultimately carried on because of a water crisis, which illustrates the government's tendency to delay crucial infrastructure improvements until an emergency occurs. Moreover, this work does not prevent remaining challenges to the system from posing risks in the near future.

\section{The Impact of Continued Mismanagement}

By March 2016, drought conditions improved in São Paulo as regular rainfall resumed. The city's reservoirs, however, remained approximately 20 percent below the pre-crisis average as of the following month. On 7 March 2016, Governor Alckmin publicly announced "the official end of the water crisis," a controversial statement that was challenged by many for being exceedingly premature and risky. The Brazilian Institute of Consumer Defense (IDEC) denounced the proclamation as untimely, and its technical manager, Carlos Tadeu de Oliveira, told the press that "having a good rainy season does not give enough assurances. This is not the moment to go back to operating as before the crisis." 52 Poor planning and mismanagement, such as that represented in Alckmin's announcement, help to create conditions for water insecurity in Brazil.

Alckimin's declaration was followed a month later by an announcement of the end of the successful water bonus program. Those announcements scored well politically for government officials in the short term but could prove to be detrimental in the long run to the water supply in São Paulo's metropolitan area.53 Without any water-saving incentives, the population may again increase water consumption to predrought levels. Unsurprisingly, by the summer of 2019, water consumption had again increased, and some reservoirs throughout the state were nearly dry.54 
The water-saving bonus program had successfully helped reduce the population's water consumption level during the height of the drought, which contributed to changing the "endless water" mentality that had prevailed before. A lack of water savings incentives could undo newly restrained water-savings attitudes and lead to the return of previous high water use. In sum, such abrupt announcements send the population mixed signals, suggesting that it might be safe to resume higher levels of water consumption at a time of little assurance regarding the future of water supply in the state.

Above all, rushing to end efforts to reduce consumption in order to balance SABESP's cash flow could be counterproductive in the long run. Once again, the motive for such an untimely cut to incentives may also be the government's old habit of sacrificing long-term benefits for the common good in exchange for short-term political gains. The reason SABESP's bonus program succeeded during the crisis was that it was able to persuade the population to save water and reduce consumption. However, the bonus program had a shortterm negative effect on the company's finances. SABESP saw its earnings plummet with the bonus program because the company had to pay millions of reais to those who saved water.55

Despite Alckimin's end-of-the-crisis rhetoric, SABESP announced in early 2016 that it would reduce its investments in waste management and sewage by 44 percent to continue funding necessary water supply infrastructure projects. Nevertheless, the company planned to increase its investments in sewage collection and treatment in 2017. Notwithstanding water-level improvements in the reservoirs, water supply in some parts of the city of São Paulo still had not returned to normal, and water rationing continued throughout most of 2016.56

Other imprudent decisions made during the crisis are now resurfacing, resulting in the continuation of water waste. During the height of the water 
crisis, half of the water saved or rationed by SABESP was achieved by reducing pressure on the grid. That risky action not only increased the danger of water contamination but also had the potential to cause more problems. As SABESP gradually returns water pressure to the grid, the old pipes are bursting, and water leakage has resumed.57 As of January 2017, SABESP claimed that it had begun upgrading and repairing $64,000 \mathrm{~km}$ of old pipes, an operation that may take several years. However, despite reporting on repairs done to specific areas in response to complaints, the company's website did not disclose what percentage of the total grid it had repaired to date.58 Furthermore, other factors that cause water loss-including replacing or repairing wasteful water consumption measuring systems that account for the underbilling of 54 percent of all water consumed in the city and reducing clandestine connections to the grid—were not resolved then, either.59

\section{How Pollution Contributed to the Water Crisis}

While large rivers possess a natural ability to filter out pollutants, large quantities of contamination by industrial, agricultural, and household sewage are overwhelming Brazil's basins and causing significant environmental degradation-particularly to the Paraná and Tietê Rivers. Industry and agriculture are responsible for 98 percent of water consumption from the Paraná Basin, which currently supplies water to those in both Argentina and Brazil. This percentage is expected to increase due to increasing land use for soybean farming and growing electricity needs, which will likely exacerbate the effects of climate change and possibly lead to the desertification of the basin. 60

In Brazil, there are many polluted rivers near large metropolitan areas. For example, the Tietê River, the largest river in the state of São Paulo, is extremely polluted.61 A group of legislative consultants with the Brazilian Federal Senate 
published an official report in which they identify, in detail, the leading causes of water pollution. Their findings specifically address the Tietê River:

The main reason for the pollut[ed] water supply sources is due to illegal urban developments built in the immediate surrounding areas of the river beds. Many of these illegal land occupations are not only tolerated but also promoted by government agencies, even if only indirectly. The fragility of soil usage inspection services, coupled with a tolerance of the practice of clandestine water, sewage and electrical connections, and lack of planning for utilities for new settlements but not yet included in a land settlement plan generate incentives for building in environmentally protected areas and of at-risk areas. 62

Figure 2. Tietê River and Marginal Tietê

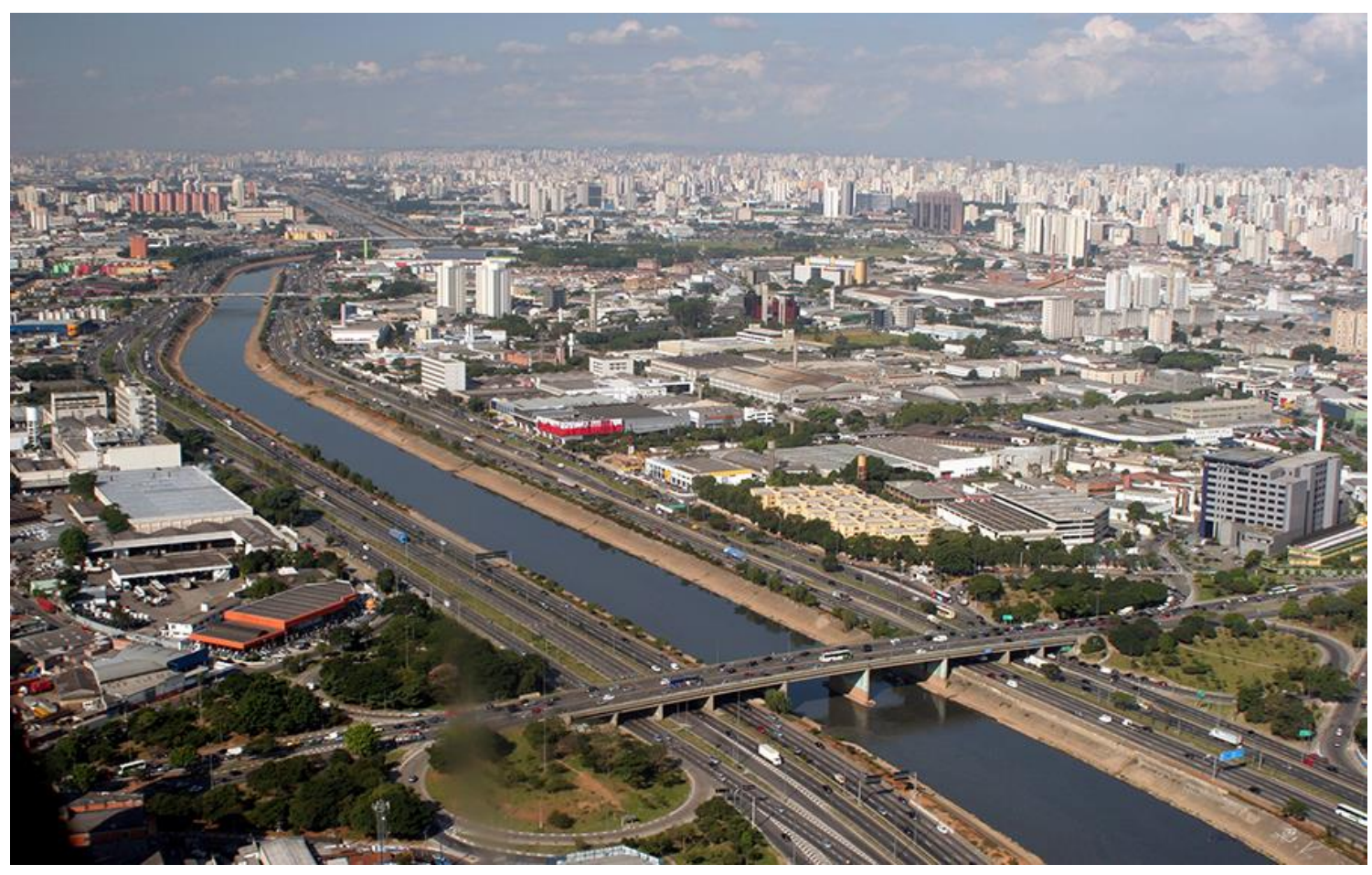

A view of the Tietê River and Marginal Tietê, the main highway in São Paulo. Source: Ana Paula Hirama. 
Since the population cannot use Tietê River water due to its high level of pollution, the amount of fresh, potable water in the area has shrunk, adding to the factors that created the water crisis in São Paulo. Worse, government officials take direct and indirect roles in fomenting conditions to allow pollution to continue and to increase. Such pervasive practices are not unique to the pollution of the Tietê. UNESCO explains the impact of pollution on water quality that Brazilians and others have faced: "Poor water quality has multiple health and environmental consequences which make the water unfit for use, hence reducing water resource availability. Indeed, water pollution is becoming one of the greatest threats to freshwater availability and re-use." UNESCO's reports identify water pollution as a direct cause of aggravating water scarcity conditions throughout the world, as does this author in the case of Brazil. Therefore, to counter water scarcity, governments need to focus on maintaining water quality, depolluting rivers, and developing mechanisms to prevent the pollution of riverbeds.63

During the water crisis, Newsha K. Ajami, director of the Water in the West program at Stanford University, was invited by the government of São Paulo to assess the drought situation due to her expertise in dealing with extreme drought in California. During an interview with the press, she commented that she "was surprised that simpler actions had not been attempted, such as the utilization of a rainwater harvesting system" or "an urgent concerted effort [made] to depollute the Tietê River that crosses the large metropolitan area." 64 What seems evident to Ajami has not been so to Brazilian officials, who opted to create new projects to tap water sources increasingly farther from São Paulo instead of implementing a plan to decontaminate one of the most important rivers in the state. 
According to their current environmental policies: "[SABESP] understands its responsibility as a Citizen Company, which treats and benefits the most important existing natural resource. Therefore, it sets guidelines for environmental management and develops solutions that contribute to sustainable development."65 An in-depth look at how SABESP implements its policies, however, reveals few beneficial results. For instance, during the cleanup of the severely polluted Tietê River, entitled Project Tietê and started in 1992, billions of dollars were spent, but the cleanup has been erratic and remains far from complete.66 Such efforts became a never-ending project that has been interrupted several times for lack of funds, mismanagement, and inadequate planning.

Figure 3. Poluição no Rio Tietê em Salto

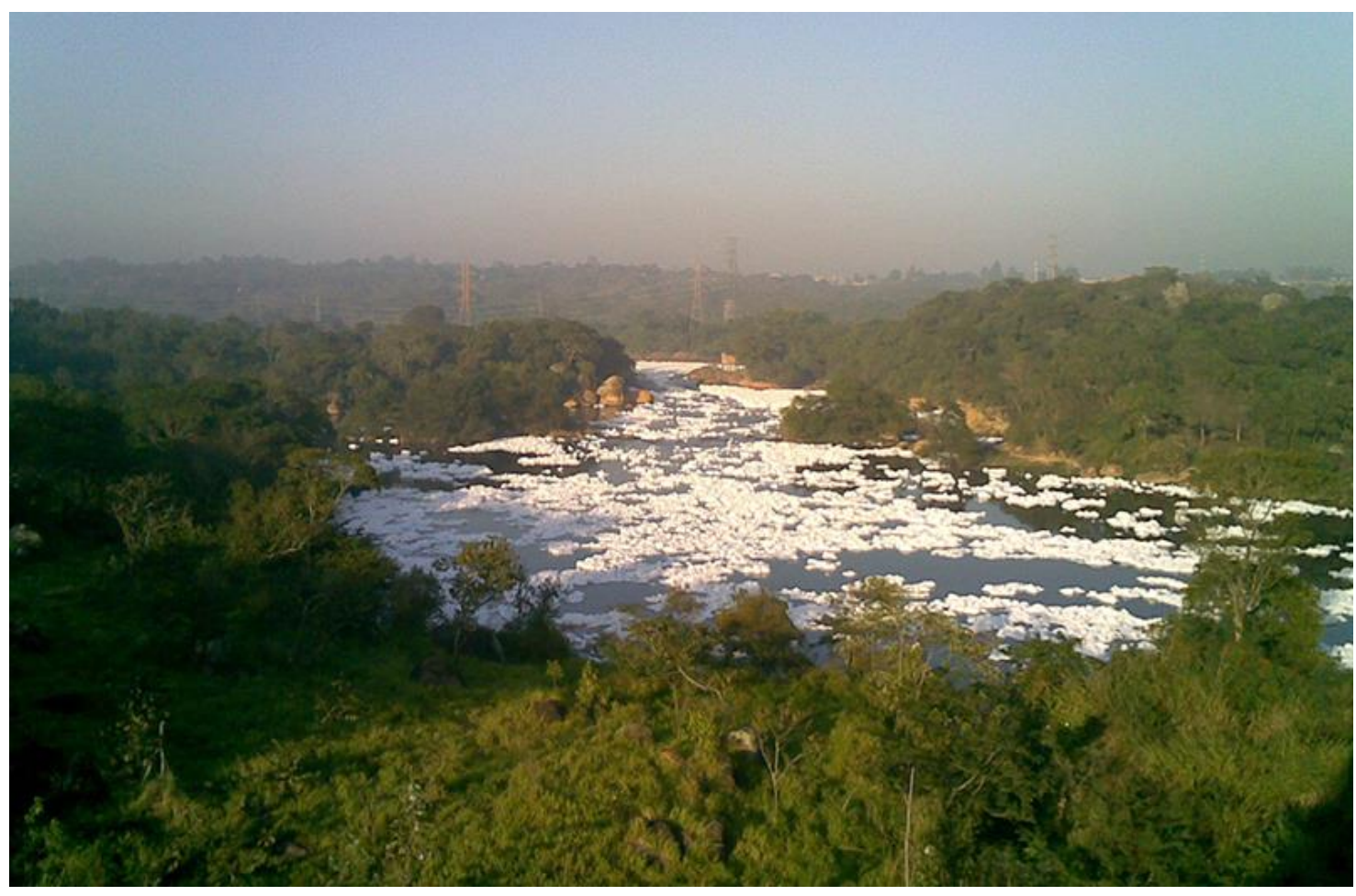

Pollution in the Tietê River, ca. 2007. Source: Wikimedia Commons/zardeto. 
SABESP's incomplete cleanup of the Tietê River is illustrated on the company's website, which lists a multitude of projects undertaken in three phases since 1992. Unfortunately, SABESP measures progress by counting the millions spent rather than by identifying the results achieved during each phase. According to the published numbers, the government spent a total of $\$ 1.1$ billion between 1992 and 1998, with $\$ 900$ million financed by IDB and $\$ 200$ million coming from other sources. During the second phase, between 2000 and 2008 , the project consisted of works totaling $\$ 500$ million, $\$ 200$ million of which came from IDB, and the remaining $\$ 300$ million from local sources. The third phase, lasting from 2009 to 2015 and amassing $\$ 600$ million from IDB and \$168 million from the National Development Bank, was interrupted for "lack of funds" and has remained unfinished. This occurred during the same time that Brazil financed billions of dollars in infrastructure projects in other countries, such as the Mariel Special Development Zone in Cuba, with Brazilian taxpayer money. The reality is that after two decades and more than $\$ 3.6$ billion spent, the Tietê River is still heavily polluted.67

The public has noticed this lack of transparency and accountability. Many civil society organizations-including non-governmental organizations, watchdog groups, the investigative press, and the São Paulo state public attorney's office (MP) - have denounced such actions. The MP is an independent public institution empowered by Brazil's Federal Constitution to defend the social and individual interests of Brazilian society. In 2012, the MP accused SABESP of "directly and uninterruptedly dumping in the rivers, in large and small scale, raw sewage-meaning, not treated sewage, collected over many cities, polluting the Tietê Basin where those municipalities are located but also polluting the Billings and Guarapiranga reservoirs the causing grave loss to the environment and society." Even though a judge has recognized that SABESP was 
indeed guilty of illegal activity, a legal dispute regarding SABESP's deadline for ending these activities nevertheless continues.68

In this context of continuous delays, SABESP's announcement that it planned to further reduce its investments in waste management and sewage in 2016 was particularly troublesome. The company reduced its waste management investments by 37 percent in 2015 and an additional 45 percent the following year. As a result, millions of people in the city of São Paulo still do not have sewage treatment for their homes, and not all of the sewage that is collected is treated. Transparency remains a significant problem. The information available to the public is not accurate, clear, or updated. For instance, as of April 2016, SABESP's website only listed progress data related to water-sewage treatment details and percentages up to 2009.69

According to SABESP's 2015 Sustainability Report, 86 percent of sewage was collected in the São Paulo metropolitan area, 78 percent of which was treated.70 This data does not explain how many households remain unconnected to the grid and obscures other problems, as well. With an estimated population of almost 30 million in the São Paulo area, it is impossible to verify how many additional sewage connections and treatments remain undone. Moreover, sewage continues to be dumped in the Tietê River, polluting the same water source that SABESP has been in charge of depolluting since 1992.71 Though the company attempts to portray itself as progressive, active, and transparent by providing impressive numbers, any critical analysis results obtained from the cleanup of the Tietê reveals many shortcomings. For instance, SABESP blames other industries for dumping residues in the river; faults the Brazilian population for dumping trash on public highways, from which it can be carried to the river by rain; and points to clandestine sewage being dumped in the river.72 
During the peak of the water crisis in 2015, SABESP interrupted its work to decontaminate the Tietê River once more in favor of pursuing emergency measures to combat the crisis. That phase of the decontamination project and its associated contracts were approved in 2013, but as of March 2017, no further work had been done. SABESP officials claimed that the Tietê cleanup should be completed by 2018, but that was not set in stone since the company's deadlines were delayed for several years. Still, the company claims great progress: "In 1993, the polluted segment of the Tietê River extended $530 \mathrm{~km}$ [from the metropolitan area of São Paulo] to the interior [municipalities in the state]. That has been reduced by 86.6 percent and by 2014 reduced to $71 \mathrm{~km} . " 73$ Ultimately, the cleanup project has lost some serious ground due to SABESP's 36 percent reduction in investments between 2014 and 2015 to decontaminate the river, causing the pollution stain to double in size, reportedly reaching a $154.7 \mathrm{~km}$ stretch by May 2016.74 The trend continues, and by September 2019, the pollution stain in the Tiete River had stretched to $163 \mathrm{~km}$, the largest in six years.75

The reality is that despite the progress achieved in sewage collection, few cities along the river treat sewage. For example, only 12 percent of the city of Guarulhos has sewage treatment available.76 Therefore, the Tietê remains very highly polluted, since the raw sewage of more than 14 million people in metropolitan São Paulo and other cities along the course of the river continues to be dumped into it each day.77

\section{Deforestation of Ciliary Forests}

The thick vegetation found along streams and riverbeds, commonly referred to in Brazil as ciliary forests, prevents soil erosion and soil loss. Ciliary forests inhibit erosion; filter the sediments brought by torrential rains; and prevent pollutants, 
such as agro-toxins used on farms, from reducing water quality. State officials from Embrapa and other agencies claim that studying the urban development and subsequent demographic occupation of the counties in the area of the Cantareira and within a $90 \mathrm{~km}$ radius of São Paulo is crucial to understanding the problem. They see a direct correlation between the unplanned urbanization of that area; the destruction of the ciliary forest along $8,171 \mathrm{~km}$ of the Tietê River; and the depletion of the Cantareira water system. As these state officials explained, the connection between deforestation and water scarcity is clear. The ciliary vegetation keeps soil moist, which prevents a "sponge effect" when rain falls on scorched soil and is quickly absorbed into the ground. The vegetation also helps maintain supplies of water to avoid drought and control flooding.78

All riverbeds need this type of natural regulation caused by ciliary forests. Embrapa officials and scientists from the University of Campinas and the University of São Paulo have different ideas to recover the ciliary vegetation in the Cantareira area, but they all agree that tree replanting must take place. Embrapa officials propose "planting of up to 30 million trees to recompose the ciliary forest in $[84,015$ acres] to comply with the new Forest Code . . . which would allow the recovery of the native forest to begin affecting the Cantareira System in 5 years." 79 The University of São Paulo's recovery project requires half that amount of trees to be replanted, since an estimated 25 percent of the vegetation would self-regenerate while 25 percent more would only require the replanting of more diverse species in the area to foster the remainder of the selfregenerating process.80 In either case, the government would need to invest heavily in the regeneration of the ciliary vegetation.

On a small scale, SABESP has policies that promote native tree planting around dams by companies that are required by law to offer environmental compensation for their polluting actions. For example, the highway development 
company Dersa, responsible for cutting hundreds of thousands of trees to build roads, has planted 1.13 million trees across 1,368 acres. Also, the government of São Paulo created the Ciliary Forest Program in 2015 to recover 49,421 acres of trees. Businesses seeking environmental licenses or landowners who need to validate ownership papers provide the resources that finance this replanting program.81 However, despite the good intentions of the reforestation programs completed so far, they fall considerably short of the scientists' recommendations and are of insufficient scope to make a difference in the Cantareira region within the next five years.

\section{Climate Change and the Deforestation in the Amazon}

In addition to the loss of ciliary forests and the catastrophic effects on the water supply in the Cantareira region, other regional climate-related phenomena are contributing to the severity of the water crisis in São Paulo. Brazil's weather patterns could change with the loss of the Amazon rainforest and the unplanned growth of cities. Antonio Donato Nobre, a researcher at the INPE, stated that the logging and burning of the Amazon are directly correlated to worsening droughts, such as that in São Paulo and many other cities in the country, and are likely to lead to more extreme weather events. Augusto José Pereira Filho, a hydrometeorology expert at the University of São Paulo, claimed that "the microclimate of São Paulo was affected by population growth and urban expansion, which create a heat-island effect and reduce the amount of low cloud cover." 82

Nobre produced a report based on the findings of more than 200 studies tracking South American rain clouds.83 According to those studies, which were presented at the United Nations Climate Change Conference in Lima, Peru, in December 2014, the devastation of the Amazon is changing the climate of the 
entire continent.84 The destruction of the Amazon caused by logging, farming, and ranching has weakened the moisture-generating mechanism. According to Nobre, "the Amazon pumps into the atmosphere the humidity that transforms into rain in the Midwest, Southeast and South regions of Brazil. The larger the deforestation, the less humidity and therefore less rain. Without the rain, the reservoirs are empty, and the taps dry." 85

Gérard Moss was one of many scientists in Brazil who agreed with Nobre's theories. He is the founder of the Flying Rivers Project, which measured how much water vapor clouds of moisture, nicknamed "flying rivers," carry from the rainforest. From 2007 to 2012, in cooperation with prominent Brazilian scientists, he gathered samples from those clouds via airplane and brought them to research labs. The leading theory behind the Flying Rivers project is summarized as follows:

The moisture-laden trade winds initially bring humidity off the Atlantic to the mouth of the giant river and then carry it inland across the continent in an on-going process of rainfall/evapotranspiration/ rainfall until coming up against the wall of the Andes. As the Cordillera forces the winds to swerve southwards, they continue carrying the moisture generated by the forest to other regions of the continent. The big question is what might happen in the south if the rainforest is destroyed to make way for yet more pasture, soya, and sugarcane ... if the hydrological cycle stops pumping out such huge volumes of humidity? 86

In 2014, the INPE published a statement with the results of the water measurements from the Flying Rivers Project, which concluded the following:

It was proved that more than half of the rainwater in the Midwest, Southeast, [and] South of Brazil, and also Bolivia, Paraguay, Argentina, 
Uruguay, and even in the extreme south of Chile, comes from the Amazon. The results include satellite images that follow the rain path [and verify] that the great drought that afflicted the Midwest and the Southeast of Brazil was in part related to the deforestation of the Amazon. Research findings also point out that in the state of São Paulo, the devastation of the Atlantic Forest allows for the formation of a hot air mass in the atmosphere. The hot air mass is so dense that it blocks the "flying rivers" and they end up empty in the states of Acre and in Rondonia (in the North), where the largest floods in history have been recorded in 2014.87

Dr. Philip M. Fearnside highlighted yet another climate-related phenomenon that affects drought conditions in São Paulo: "The future of transportation of water vapor to São Paulo depends not only on the source of water vapor in the Amazon but also on the strength of the [South American lowlevel jet winds (SALLJ)]." He explained that "alterations in the SALLJ can compensate for the supply of reduced water vapor by deforestation," but in the future, the strength and frequency of these episodes are directly related to $\mathrm{El}$ Niño. Even though he admitted that there is not sufficient evidence to completely confirm this connection, Fearnside suggested that "it is more likely that a combination of factors reduced the water condensation vapors present in the air over São Paulo" during the drought. "A mass of hot air laying over the State of São Paulo inhibited the entrance of cold fronts that normally cause condensation of water vapors to generate rainfall." He continued, "There was also [the] dislocation of the South Atlantic Convergence Zone (SACZ) to the north, passing over the border between the states of Minas Gerais and Bahia, instead of its normal position above São Paulo, which removed an important 
mechanism to create rainfall precisely in 2014-2015." Fearnside concluded that most of those events result from global warming, but warned that persistent deforestation in the Amazon will lead to a drought in the metropolitan region of São Paulo—not a cyclical drought, but a permanent one.88

To counter deforestation, Brazil implemented a surveillance program in 1988 entitled PRODES project, which employed a satellite system to monitor deforestation in the Brazilian Amazon.89 The project estimates total deforestation each year using about 220 LANDSAT/CBER satellite images.90 Today, its existing data is available on the internet. For data reporting, PRODES only considers "low-cut" deforestation, which counts land that is entirely deforested or has suffered a total area clearing.91 Other statistics are incorporated to account for partially destroyed areas.92 The official 2015 PRODES estimate of low-cut deforestation in the Brazilian Amazon is 5,381 sq km, while the total deforestation registered between 1988 and 2015 was 413,506 sq km.93 Nobre observed that "over the past 40 years, nearly 20 percent of the Amazon has been destroyed . . . an area twice the size of Germany . . . while an additional 22 percent has been seriously compromised." 94

Beyond satellite monitoring, the Brazilian government has also adopted environmental protection laws and designated indigenous reservations and forest conservation zones, but unlawful logging nevertheless continues.95 That vast region, sparsely populated throughout history, is now among Brazil's fastest-growing. Its population has increased 23 percent between 2000 and 2010, and many cities continue to expand today. 96

Forest clearing declined when satellite monitoring began, but it increased considerably in 2014 under President Rousseff, when perceptible efforts to protect the Amazon gave away to renewed political lobbying pressures. Satellite data indicated that "a 190 percent surge in deforestation" had occurred in 
August and September of that year.97 Fearnside stated that "the government hid these figures before the [2014 presidential] election."98 The government also manipulated other essential numbers in the federal budget and committed fiscal fraud, which was one of the reasons that Rousseff's impeachment proceedings were later initiated by the lower house of the National Congress in April 2016.99 The strategy used by Rousseff's government paid off, and she won a second term by a very narrow margin in the 2014 election. Fearnside called the delayed data publication "a scandal" because "the August and September data would normally have been released in October [before the 26 October presidential election]. However, they sat on the data, and it was not disclosed until the end of November." 100

Deforestation in the Amazon typically occurs as a result of both legal activities, such as road building and the construction of hydroelectric dams, and illegal activities, such as land clearing for pasture, mining, and logging. While soybean planting takes place mostly on land previously cleared for pasture, additional deforestation occurs mostly because the soybean trade requires the buildup of transportation infrastructure. The construction of roads, barrage systems, and railroads, as well as the increased migration associated with these activities, causes cumulative pressure for more deforestation.

Many economic factors correlate with higher rates of deforestation. For example, deforestation often occurs when soybean prices are high, and the commodity is in strong demand in the international market. Fearnside explains that deforestation rates throughout the Brazilian Amazonia have declined substantially since 2004, which coincided with a decline in demand for the product, culminating in the 2008 world financial crisis. The association between falling international prices of soy and beef between 2004 and 2006, coupled with a worsening exchange rate of the Brazilian real, did not benefit exporters at that 
time. Although commodity prices came back up between 2008 and 2012, the exchange rate only recovered in 2012. With higher soy and beef prices recorded in recent years, the pressure to clear land for building infrastructure to transport soy has significantly increased again.101

Indeed, since 2014, the increase in both the supply and demand of soy and beef in the international market explains the pressure shift from conservation to "development" of the Amazon-which is, in this case, a synonym for deforestation. The federal government's actions in the Amazon were a direct response to the influence of the ruralistas, the soybean agribusiness lobby in the National Congress. This renewed interest in the economic development of Amazon promotes the election of officials that are pro-business rather than proconservation. In many instances, a strong agribusiness base throughout Brazil elected current government officials who have pushed their progressive economic-profit agenda in detriment of environmentally responsible measures.

As a result of the ruralista lobby, the federal government allowed for the enactment of new laws and regulations that clash with the 1988 Constitution's environmental provisions. Accordingly, Fearnside claims that the Forest Code enacted in 2012 "weakens critical environmental protections and also offers an amnesty for all those who violated environmental laws before 2008. So if you cleared illegally, you got away with it. And the expectation is that if you clear illegally now, there will eventually be another amnesty that will forgive your past crimes. On the other hand, if you actually obeyed the law, you lost money. So the incentives are very perverse." 102

Another example of conflicting interests within the federal government comes from an unexpected source. Brazil's most potent grassroots movement, Movimento dos Trabalhadores Rurais Sem Terra (Landless Rural Workers Movement), a radical Communist organization known as MST, remains an 
influential force. Since its inception, MST has committed more than 2,500 illegal land occupations. The Brazilian Socialist Workers Party (PT), which has been in power since 2003, claims to be MST's main backer, but PT's actual support for the organization has stalled because PT's political base in agricultural states depends heavily on the support of the powerful agribusiness lobby. These clashing interests have created a dilemma for PT politicians and the MST. An MST leader described their difficult situation in 2016:

The [former president] Lula government still maintained a reasonable pace of expropriations, although not very different from [former president] Cardoso's government. In [then-president] Rousseff's government, this process is totally paralyzed, the result of a correlation of more hostile forces, the social and political background that makes up the government, and a stunning lack of operational competency in the sectors that constitute the government. 103

\section{Conclusions}

The extended drought and ensuing water crisis in Brazil during 2012-15 introduced a new reality to the country: Brazil can no longer assume water supplies are infinite, especially during periods of rising temperatures and diminishing rainfall. Although the initial Brazilian reaction is to assume the worst is over, the reality is that the natural and human factors contributing to the crisis show no immediate sign of abatement. The drought was a wakeup call that exposed real problems, including decades of government failures, gross mismanagement of water resources, inadequate implementation of the Water Code and related laws, and abysmal planning for temporary climate-related water shortages. 
The water crisis also exposed the severe consequences related to a lack of transparency in large infrastructure public works projects and almost no accountability for these actions. The pollution of the Tietê River is not a unique mishap in the country, as the scandal stemming from the polluted Guanabara Bay in Rio de Janeiro during the 2016 Olympic Games exposed to the world. The two pollution cleanup efforts that included multibillion financing suffers from a lack of measurable results, offering proof that government leaders need to be held accountable for malign systemic failure and the lack of enforcement of the rule of law in Brazil.

The solutions for the water scarcity problems in São Paulo are not simple and demand societal and governmental actions. The tasks ahead are immense but necessary to ensure sufficient water supply for the population, industry, agriculture, and energy production of both the city and state of São Paulo. The enormous challenges include many unknown variables of global climate change. If experts are right, regional climate changes, punctuated by deforestation of the Amazon, may affect Brazil's long-term rainfall patterns. The pollution of large rivers and bays adds challenges to the drought scenario, and resources and efforts to clean up these polluted areas are pushed aside and give way to newer, more urgent water scarcity projects. However, in the case of São Paulo, as water supplies dwindle with seasonal or unpredicted weather-related events, cleanup of the Tietê River should remain a priority, as well as replanting and recovering its ciliary forests.

Finally, there is an urgent need for a complete overhaul of water and sewage management toward more effective long-term planning, accompanied by equally trackable and transparent practices. It is also necessary to reverse the trend responsible for significant recent cuts in sewage collection and treatment. As SABESP further reduces these efforts, pollution will continue to increase in the 
Tietê River. There remains a significant need for a renewed focus on sewage collection and treatment for the entire population, an upgrade of outdated infrastructure, and continual education of the population on water conservation and pollution prevention.

In the light of the current political crisis in Brazil, which has severely affected the economy and diminished the federal government's ability to focus on, finance, and execute many infrastructure projects, the outlook is bleak. Brazil's hopes lie in badly needed changes that will result in a real financial gain for the public coffers instead of introducing unnecessary costs-a change in the culture of political corruption and graft. The whole of Brazilian society needs to be involved through the persistence of civil society, armed with democratic values founded on complete government transparency and the rule of law.

\footnotetext{
1 Rosa Maria Formiga Johnsson and Karin Erika Kemper, Institutional and Policy Analysis of River Basin Management: The Alto-Tietê River Basin, São Paulo, Brazil, Policy Research Working Paper 3650 (Washington, DC: World Bank, 2005), 16.

2 Ellen Gray, "GRACE Satellites Evaluate Drought in Southeast Brazil," NASA Global Climate Change, 28 October 2015; Jonathan Watts, "Brazil's Worst Drought in History Prompts Protests and Blackouts," Guardian, 23 January 2015; and Jonathan Watts, "Brazil Drought Crisis Leads to Rationing and Tensions," Guardian, 5 September 2014.

3 "Brazil: Topography," Encyclopedia of the Nations, accessed 11 March 2016; "Região Hidrográfica Amazônica," Agência Nacional de Águas, accessed 28 July 2016; and Mauri Cesar Barbosa Pereira, "A Gestão das Águas Transfronteiriças e a Hidropolítica," Aguas do Brasil no. 6 (May 2013): 12-17.

4 "Xingu River," International Rivers, accessed 25 April 2016.

5 "Tapajós River," Encyclopædia Britannica, accessed 25 April 2016; and Jenni Avins, "Brazil Has More Freshwater than Any Other Country, But Its Biggest City Is Running Dry," Quartz, 26 February 2015.

6 For the purposes of this discussion, the term megacity refers to a city with a population of more than 10 million people. "Região Hidrográfica Amazônica"; and "Cidades e Estados," Instituto Brasileiro de Geografia e Estatística, accessed 11 May 2016.

7 Marcelo Leite et al., "Crystal Unclear: A Future for Water Resources in Brazil," Folha de São Paulo, 15 September 2015.

8 UNESCO, "Water Scarcity," factsheet, accessed 11 April 2016.

9 "Climate Change: How Do We Know?," NASA Global Climate Change, accessed 27 July 2016.
} 
10 Richard Connor et al., "Climate Change and Possible Futures," in The United Nations World Water Development Report 3: Water in a Changing World (Paris: UNESCO Publishing and London: Earthscan, 2009), 72.

11 "What Are El Niño and La Niña?," National Ocean Service, National Oceanic and Atmospheric Administration, accessed 17 March 2016; and Brian W. Blouet and Olwyn M. Blouet, Latin America and the Caribbean: A Systematic and Regional Survey, 6th ed. (Hoboken, NJ: John Wiley, 2009), 16.

12 "South America Summer Forecast: El Nino to Bring Flooding Rain to Argentina, Uruguay and Southeast Brazil," AccuWeather, 1 November 2015.

13 Caio A. S. Coelho et al., "The 2014 Southeast Brazil Austral Summer Drought: Regional Scale Mechanisms and Teleconnections," Climate Dynamics 46, no. 11-12 (June 2016): 3737-752, https://doi:10.1007/s00704-015-1540-9; and Philip M. Fearnside, "Rios Voadores e a Água de São Paulo 4: As Razões da Seca de 2014-2015," Amazônia Real, 2 March 2015.

14 Fearnside, "Rios Voadores e a Água de São Paulo 4."

15 Wenju Cai et al., "Increasing Frequency of Extreme El Niño Events Due to Greenhouse Warming," Nature Climate Change 4 (2014): 111-16, https://doi.org/10.1038/nclimate2100.

${ }_{16}$ Caio A.S. Coelho et al., A Seca de 2013 a 2015 na Região Studeste do Brasil (São Paulo, Brazil: Centro de Previsão de Tempo e Estudos Climáticos, Instituto Nacional de Pesquisas, 2016).

17 "CPTEC/INPE Diagnostica e Propõem Mecanismos Causadores da Seca Ocorrida Durante O Verão de 2014 na Região Sudeste do Brasil," Centro de Previsão de Tempo e Estudos Climáticos, Instituto Nacional de Pesquisas, accessed 24 February 2017.

${ }_{18}$ Coelho et al., A Seca de 2013 a 2015 na Região Studeste do Brasil.

19 "São Paulo's Water Crisis: Reservoir Hogs," Economist, 17 December 2014.

20 "São Paulo: Resultados Por Município," Agéncia Nacional de Águas, accessed 28 July 2016.

21 "About SABESP: Profile," SABESP, accessed 17 March 2016.

22 Watts, "Brazil's Worst Drought in History Prompts Protests and Blackouts."

23 Fabrício Lobel and Gustavo Uribe, "Governo de SP Encontra Nova Reserva de Água no Sistema Cantareira," Folha de São Paulo, 2 October 2015.

24 Watts, "Brazil's Worst Drought in History Prompts Protests and Blackouts."

25 Código de Águas, Decreto no. 24.643 de 10 de Julho de 1934, Governo Provisório da República dos Estados Unidos do Brasil (1934).

26 "Water Resources Management in Brazil," Agéncia Nacional de Águas, accessed 27 July 2016.

27 "National Water Agency (ANA)," Agéncia Nacional de Águas, accessed 27 July 2016.

28 "IHP-VIII: Water Security," UNESCO, accessed 11 April 2016.

29 "Overview of Key Messages," The United Nations World Water Development Report 3, xxi.

30 "Overview of Key Messages," xxi.

31 David Biller and Michael Smith, "Rio Promised to Clean Up Guanabara Bay Before the Olympics," Bloomberg Businessweek, 28 July 2016.

32 "BR-L1282: Environmental Sanitation Program for Municípios in the Guanabara Bay AreaPSAM," Inter-American Development Bank, accessed 2 August 2016.

33 Biller and Smith, "Rio Promised to Clean Up Guanabara Bay Before the Olympics."

34 Biller and Smith, "Rio Promised to Clean Up Guanabara Bay Before the Olympics."

35 "Documents \& Reports: Corruption," World Bank, accessed 2 August 2016; and "Transparency: How to Report Fraud and Corruption?," Inter-American Development Bank, accessed 2 August 2016.

36 "Overview of Key Messages," 49, 55. 
37 Elaborado por Gustavo Aouar Cerqueira et al., "A Crise Hídrica e Suas Consequências," Boletim do Legislativo no. 27 de 2015 (Brasília, DF: Núcleo de Estudos e Pesquisas, CONLEG, Senado, 2015).

38 Cerqueira et al., "A Crise Hídrica e Suas Consequências."

39 Cerqueira et al., "A Crise Hídrica e Suas Consequências."

40 Carina Bezerra Kobashigawa, "Gerenciamento Hídrico Urbano no Município de São Paulo," Jusbrasil, 24 September 2015; and "Tubulação Velha Causa Desperdício de Água em SP," Veja, 23 April 2014.

41 Gesner Oliveira et al., Perdas de Água: Desafio ao Avanço do Saneamento Básico e ã Excasses Hídrica (São Paulo, SP: GO Associados, 2015), 28-29.

42 Oliveira et al., Perdas de Água, 12, 33, 111.

43 Renato M. Coutinho et al., "Catastrophic Regime Shift in Water Reservoirs and São Paulo Water Supply Crisis," PLOS ONE 10, no. 9 (September 2015), 12, https://doi.org/10.1371/journal.pone.0138278.

44 "São Paulo's Water Crisis."

45 Watts, "Brazil's Worst Drought in History Prompts Protests and Blackouts."

46 Fabrício Lobel e Monique Oliveira, "Grande São Paulo Tem Em Media 14 Horas de Torneira Seca ao Dia," Folha de São Paulo, 28 January 2015; and Fabrício Lobel, "Principal Aposta da SABESP, Redução de Pressão Pode Contaminar Água," Folha de São Paulo, 20 January 2015.

47 "Estoque de Água em São Paulo Cai 74\% Em Um Ano," Veja, 25 January 2015.

48 Suzanne Ozment et al., Natural Infrastructure in São Paulo's Water System (Washington, DC: World Resources Institute, 2018), 14-15.

49 "Interligação do Rio Paraíba do Sul Com o Cantareira Recebe Aval Ambiental," Folha de São Paulo, 1 January 2016.

50 Ozment et al., Natural Infrastructure in São Paulo's Water System, 16.

51 Roney Domingos, "Após Falha, Alckmin Entrega Obra que Vai Levar Água da Billings ao Alto Tietê," G1, Grupo Globo, 30 September 2015.

52 "Crise da Água: Fim do Bônus e Sobretaxa da SABESP é Inoportuno, Diz Entidade," Folha de São Paulo, 1 April 2016.

53 "Crise da Água."

54 "Calor e Consumo Alto Baixam Reservatórios e Causam Falta de Água no Interior," Istoê, 11 February 2019.

55 Fabrício Lobel, "Mesmo 'Sem Crise,' SABESP Deve Cortar 45\% dos Investimentos em Esgoto," Folha de São Paulo, 29 March 2016.

56 "Investimentos Realizados Por Trimestre (R\$ Milhões)," SABESP, accessed 27 February 2017.

57 Isabela Leite, "Após Liberar Mais Água na Rede em SP, SABESP Tem Aumento de Vazamentos," G1, Grupo Globo, 10 March 2016.

58 "SABESP Já Executou Conserto de Tubulação," SABESP, 31 January 2017.

59 Watts, "Brazil's Worst Drought in History Prompts Protests and Blackouts"; and Leite, "Após Liberar Mais Água na Rede em SP, SABESP Tem Aumento de Vazamentos."

60 Connor et al., "Climate Change and Possible Futures," in The United Nations World Water Development Report 3, 67, 72.

61 Giulia Afiune and Jessica Mota, "Projeto Tiête," Agencia Publica, 13 July 2015.

62 Cerqueira et al., "A Crise Hídrica e Suas Consequências."

63 "Water Scarcity and Quality," UNESCO.

64 Giuliana Vallone, "SP Deve Mirar Curto Prazo Na Luta Contra Crise Da Água, Diz Pesquisadora," Folha de São Paulo, 19 January 2015. 
65 "Environmental Policies' Excerpt," SABESP, accessed 30 March 2016.

66 Afiune and Mota, "Projeto Tiête."

67 "Projeto Tiête III," SABESP, accessed 30 March 2016; Maria C. Werlau, "Paying for the Port of Mariel: Are Cuba and Brazil Partners in Human Trafficking?," Cuban Economy, 24 October 2014; and Afiune and Mota, "Projeto Tiête."

68 "O Que É O Ministério Público," Ministério Público de São Paulo, accessed 12 April 2016; and Afiune and Mota, "Projeto Tiête."

69 Lobel, "Mesmo 'Sem Crise,' SABESP Deve Cortar 45\% dos Investimentos em Esgoto"; and "Notícias: Tratamento de Esgoto Para Quase 3 Milhões de Pessoas," SABESP, accessed 13 April 2016.

70 Sustainability Report, 2015 (São Paulo, Bazil: SABESP, 2015), 12.

71 "Notícias: Tratamento de Esgoto Para Quase 3 Milhões de Pessoas"; "Números," SABESP, accessed 13 April 2016; and "22 de Setembro: Dia do Rio Tiête," SABESP, accessed 24 May 2016.

72 "Relatório de Sustentabilidade 2015."

73 Fabrício Lobel, "SABESP Trava Obras Para Despoluição do Rio Tiête em São Paulo," Folha de São Paulo, 14 September 2015.

74 Leo Acorverde, "Investimentos em Despoluição do Tietê Caem em 36\% e Mancha de Poluição Cresce," Universo Online, 18 May 2016.

75 Renato Biazzi, "Mancha de Poluição do Rio Tietê Avança e Atinge 163 km, Maior Extensão em 6 Anos," G1, Grupo Globo, 18 September 2019.

76 Biazzi, "Mancha de Poluição do Rio Tietê Avança e Atinge 163 km, Maior Extensão em 6 Anos."

77 Mara Gama, "Lei Ultrapassada e Conflitos de Gestão Atrasam Limpeza do Rio Tietê," Folha de São Paulo, 22 March 2016.

78 "Cantareira Precisa de 30 mi de NovasÁrvore Em Seu Entorno," Veja, 22 February 2015.

79 The Forest Code in Brazil is legislation on land management that legally requires landowners in the Brazilian Amazon to permanently maintain 80 percent of the land as forest. Brazil's New Forest Code: A Guide for Decision-makers in Supply Chains and Governments (Gland, Switzerland: World Wildlife Fund, 2015).

80 Lourival Sant'Anna, "Sob Ameaça, Cantareira Precisa de 30 Milhões de Árvores, ao Custo de R\$195 Mi," Estadão-São Paulo, 21 February 2015.

81 Lourival Sant'Anna, "Sob Ameaça, Cantareira Precisa de 30 Milhões de Árvores, ao Custo de R\$195 Mi."

82 Watts, "Brazil's Worst Drought in History Prompts Protests and Blackouts."

83 "Falta D'Água Em Cidades Tem a Ver Com a Devastação da Amazônia," Gestão de Comunicação Institucional, Instituto Nacional de Pesquisas Espaciais, 31 August 2014.

84 United Nations Framework Convention on Climate Change, accessed 14 April 2016.

85 "Falta D'Água Em Cidades Tem a Ver Com a Devastação da Amazônia."

86 "The Flying Rivers Project," Rios Voadores, accessed 14 April 2016.

87 "Falta D'Água Em Cidades Tem a Ver Com a Devastação da Amazônia."

88 Fearnside, "Rios Voadores e a Água de São Paulo 4."

89 PRODES stands for the PROmotion of renewable energy for water production through DESalination.

90 LANDSAT refers to the Landsat observation satellites that continuously acquire space-based images of the Earth's land surface in a joint NASA/U.S. Geological Survey project. CBER stands for China-Brazil Earth Resources Satellite.

91 "Projeto PRODES: Monitoramento de Floresta Amazônica por Satélite," Coordenação-Geral de Observação da Terra, INPE, accessed 14 April 2016. 
92 "Mapeamento da Degradação Florestal na Amazônia Brasileira," Coordenação-Geral de Observação da Terra, INPE, accessed 14 April 2016.

93 "Divulgação do PRODES 2015: Taxa Estimada do Desmatamento da Amazônia Legal Para Período Ago/2014-Jul/2015," Coordenação-Geral de Observação da Terra, INPE, accessed 14 April 2016.

94 Reed Johnson and Rogerio Jelmayer, "Deforestation Sparks Brazilian Debate," Wall Street Journal, 4 December 2014.

95 Blouet and Blouet, Latin America and the Caribbean, 381.

96 Johnson and Jelmayer, "Deforestation Sparks Brazilian Debate."

97 Jonathan Watts, "Amazon Rainforest Losing Ability to Regulate Climate, Scientist Warns," Guardian, 31 October 2014.

98 Richard Schiffman, "What Lies Behind the Recent Surge of Amazon Deforestation," Yale Environment 360, 9 March 2015.

99 Joe Leahy, "What Is Brazil's President Dilma Rousseff Accused of?," Financial Times, 12 May 2016.

100 Schiffman, "What Lies Behind the Recent Surge of Amazon Deforestation."

101 Philip M. Fearnside and Adriano M. R. Figueredo, "China's Influence on Deforestation in Brazilian Amazonia: A Growing Force in the State of Mato Grosso" (discussion paper, Boston University Global Economic Governance Initiative, 2015), 8-21.

102 Schiffman, "What Lies Behind the Recent Surge of Amazon Deforestation."

103 Igor Carvalho and Glacuo Faria, "The MST at 30: Far Beyond the Distribution of Land," Friends of the MST, 28 January 2014. 